\title{
Roles of melatonin and prolactin in testicular crudescence in mink (Mustela vison)
}

\author{
G. B. DiGregorio*, A. González Reyna ${ }^{\dagger}$ and B. D. Murphy ${ }^{\ddagger}$ \\ Reproductive Biology Research Unit, Department of Obstetrics and Gynaecology, University of \\ Saskatchewan, Saskatoon, Canada S7N OWO
}

\begin{abstract}
Peripubertal male mink (Mustela vison) were treated with prolactin, melatonin or antibodies against melatonin to determine the effects of altered circulating concentrations of prolactin and melatonin throughout one season of testicular development. Treatment began on 1 October and continued until 4 March. Administration of $0.5 \mathrm{mg}$ ovine prolactin day ${ }^{-1}$ by minipump increased the circulating concentration of prolactin for the duration of the study and increased serum concentrations of LH. This treatment had no effect on the testosterone concentration or on testis size. Neither chronic treatment with melatonin throughout the period of crudescence nor passive immunization against melatonin for 79 days affected the circulating concentrations of prolactin, $\mathrm{LH}$, testosterone or testis size. These results show clearly that, unlike in other seasonally breeding species, prolactin does not play a significant role in testis growth in the mink. Administration of melatonin to male mink in October did not affect testis growth, presumably because the melatonin signal that cues photoperiodic events had already been received. Administration of antibodies against melatonin did not affect any of the features measured, suggesting that melatonin may have neural but not peripheral effects. Further support for this view can be found in the absence of an influence of melatonin on testis growth or on the plasma concentration of testosterone.
\end{abstract}

\section{Introduction}

Melatonin and prolactin exhibit seasonal as well as circadian fluctuations in the plasma of mammals (melatonin: Goldman et al., 1981; prolactin: Harris and Murphy, 1981; Agu et al., 1986). The seasonal rhythms arise because synthesis and secretion of these hormones are mediated by photoperiod. In mammals, melatonin is synthesized and secreted in the dark phase of the light cycle (see review by Steinlediner and Niklowitz, 1992). In mink, as in other species, the pineal gland is the source of melatonin (Ravault et al., 1986; Tillet et al., 1989), and nocturnal plasma melatonin concentrations are increased for less time as the photoperiod increases to more than $12 \mathrm{~h}$ (Allain et al., 1981). Administration of melatonin to female mink prevents the vernal rise in plasma prolactin concentrations (Murphy et al., 1990), and exogenous melatonin administered in July suppresses endogenous prolactin concentrations in male mink (Rose et al., 1985).

In carnivores, the cycle of change in pelage (Rose et al., 1984, 1985), embryonic diapause (Murphy and James, 1974) and testicular crudescence (Duby and Travis, 1972; Allain et al., 1981) are influenced by photoperiod. Recent reports by

\footnotetext{
*Present address: Department of Physiology and Biophysics, Colorado State University, Fort Collins, CO 80523, USA.

†Present address: División Postgrado, Universidad Autónoma de Tamaulipus, Victoria, Tamaulipus, Mexico.

${ }^{\ddagger}$ Correspondence: Centre de Recherche en Reproduction Animale, Université de Montréal, CP 5000, St-Hyacinthe, Québec, Canada J2S 7C6.

Received 23 September 1993.
}

Martinet $e t$ al. $(1992 a, b)$ suggest that the annual pelage cycle is controlled endogenously, while the testicular cycle depends on photoperiodic change. The seasonal increase in testis volume that begins in October in the northern hemisphere is preceded by an increase in plasma concentrations of androgens (Pilbeam et al., 1979). Ablation of the pineal gland (Boissin-Agasse et al., 1988) or its deafferentation (Maurel et al., 1990) prevent pubertal changes if performed before the beginning of testicular growth. Administration of melatonin to adult or pubertal male mink before the onset of short days (mid-July) triggers FSH and LH secretion, inhibits prolactin secretion (Martinet et al., 1992a) and accelerates testicular growth (Allain et al., 1981; DiGregorio and Murphy, 1987). The effects of photoperiod, transduced by melatonin, on testicular growth may be reflected in the secretion of prolactin in mink. Treatment of male mink with slow-release melatonin implants in late June causes a rapid decrease in the plasma concentrations of prolactin after mid-July to concentrations similar to those found during November (Rose et al., 1985).

During long days, the duration of the nocturnal rise in serum melatonin concentrations is brief, and the concentration of prolactin is high when testis mass and the plasma concentration of testosterone are increasing in Syrian hamsters (Bartke et al., 1975). Bex ef al. (1978) reported that prolactin increases the sensitivity of the hamster testis to LH. However, this interaction was not observed in the male blue fox (Smith et al., 1987). The roles of melatonin and prolactin in the onset and completion of testicular growth in mink are not well understood. The objective of this study was to examine the effects of 


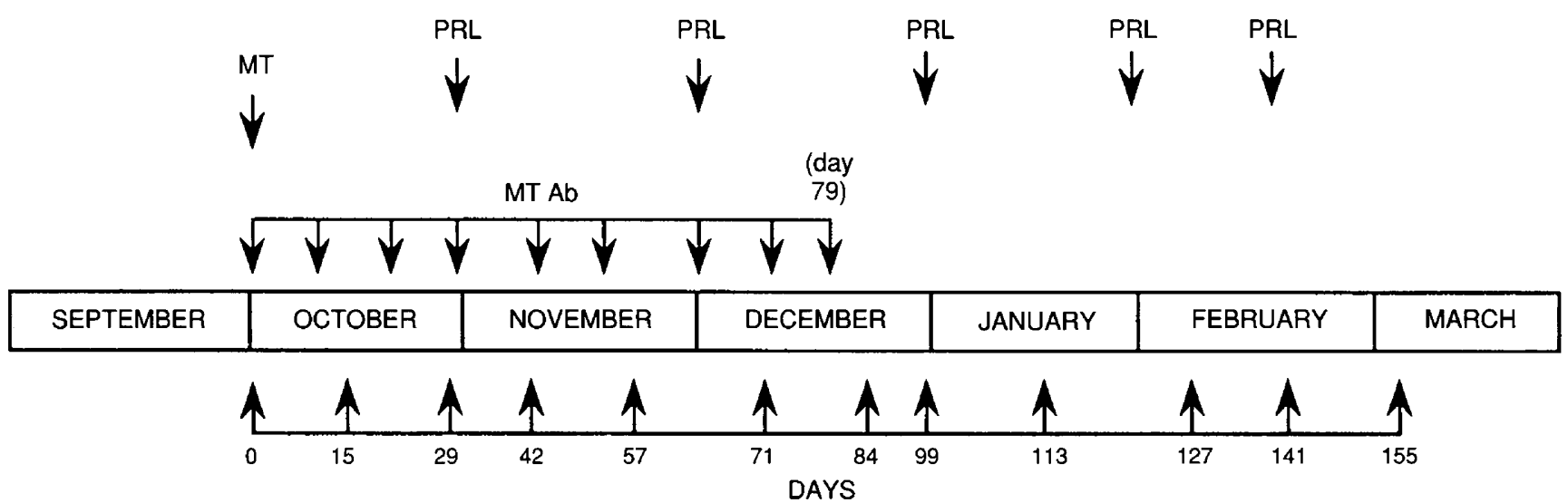

Fig. 1. Experimental design. The experiment was conducted between 1 October and 4 March. Treatment protocols are shown above the calendar axis: (i) administration of a single implant containing $5 \mathrm{mg}$ melatonin (MT); (ii) $84 \mathrm{mg}$ ovine prolactin delivered s.c. by an Alzet osmotic minipump every 4 weeks for 110 days beginning on 1 November (day 32) (PRL); and (iii) passive immunization with rabbit serum containing an antibody against melatonin once a week for 11 weeks (MT Ab). The time course for sample collections is below the calendar axis. Blood samples were collected and the length of the left testis was measured biweekly.

altered concentrations of these two hormones on gonadal development in ranch mink.

\section{Materials and Methods}

\section{Animals and treatments}

Prepubertal male mink (Mustela vison) of the Pastel variety were purchased from Montgomery Fur Ranch (Wetaskiwin, Alberta). Animals were housed outdoors under an ambient photoperiod and temperature at $52^{\circ}$ latitude. They were fed a daily ration purchased from the Montgomery Fur Ranch, consisting of fish and poultry offal, cereals, vitamins and minerals, which is a diet known to be compatible with successful reproduction. Water was provided ad libitum. The experimental protocol is illustrated in Fig. 1. Six mink received an implant containing $5 \mathrm{mg}$ crystalline melatonin (Wildlife Laboratories, Fort Collins, CO) administered s.c. on 1 October (day 0). Previous studies (B. D. Murphy, unpublished) have shown that melatonin is released linearly for 1 year from these implants. A second group of six kit males were implanted with Alzet osmotic minipumps (Palo Alto, CA) containing $84 \mathrm{mg}$ ovine prolactin (NIH AFP-8277E) on 1 November. The implant released $0.5 \mathrm{mg}$ prolactin per day and was inserted s.c. in the scapular region under general anaesthesia. The pump was replaced every 4 weeks and a final replacement was inserted on 18 February. A third group of six kit males were injected with rabbit polyclonal antiserum to melatonin every 7 days until day 79. The treatment protocol, developed in a pilot study, was such that injections of $0.5 \mathrm{ml}$ antiserum $\mathrm{kg}^{-\frac{1}{1}}$ bodymass every 7 days maintained titres of melatonin antibody detectable at 1:1000 dilution of serum. An untreated group of six kit males served as controls.

Jugular blood samples were taken after immobilization with $0.4 \mathrm{mg}$ ketamine $\mathrm{kg}^{-1}$ (Rogarsetic, Rogar ST, Montréal, $\mathrm{PQ}$ ) and the left testis was measured between $10: 00 \mathrm{~h}$ and 15:00 $\mathrm{h}$ on I October and biweekly thereafter up to day 155 of the experiment. Blood was allowed to clot overnight at $4^{\circ} \mathrm{C}$ and was centrifuged at $1000 \mathrm{~g}$ for $30 \mathrm{~min}$ to collect serum. Anti-melatonin titres were evaluated in serum from mink that had received rabbit anti-melatonin antiserum, by determining binding after incubation with $3.0 \times 10^{4}$ c.p.m. of $\left[{ }^{3} \mathrm{H}\right]$ melatonin (N-acetyl-5-methoxytryptamine, $87 \mathrm{Ci} \mathrm{mmol}^{-1}$; New England Nuclear, Boston, MA) for $15 \mathrm{~h}$ at $4^{\circ} \mathrm{C}$.

\section{Immune response to prolactin infusion}

Antibody titres against prolactin were measured in animals treated with exogenous hormone using a modification of the prolactin radioimmunoassay reported by Agu et al. (1986), in which the binding of ${ }^{125}$ I-labelled canine prolactin to diluted serum samples was determined. Total specific binding was not greater than nonspecific binding at dilutions of serum between $1: 4$ and 1:100, indicating that none of the mink developed antibodies to prolactin during its administration.

\section{Production of rabbit anti-melatonin antibody}

Rabbits were immunized biweekly for 6 weeks with $0.3 \mathrm{mg}$ melatonin conjugated to BSA. Antiserum diluted 1:1000 specifically bound $35 \%$ of $\left[{ }^{3} \mathrm{H}\right]$ melatonin added in a primary binding assay consisting of $0.1 \mathrm{ml}$ of antiserum diluted 1:1000, $100 \mu \mathrm{l}$ of $\left[{ }^{3} \mathrm{H}\right]$ melatonin at 30000 c.p.m. and PBS to a final volume of $0.6 \mathrm{ml}$. Antibodies in the plasma of the rabbit with the highest titre of melatonin antibody were purified by dialysis and passed over a DEAE Affi-Gel Blue column (BIORAD, Richmond, $C A$ ). The eluate was concentrated and dialysed against $\mathrm{PBS}$ overnight at $4^{\circ} \mathrm{C}$ and stored at $-20^{\circ} \mathrm{C}$ until administered as described above.

\section{Radioimmunoassays}

A double antibody radioimmunoassay for prolactin that had previously been validated in mink (Murphy et al., 1990) was used. The intra-assay coefficient of variation calculated between duplicates ranged from 2.1 to $9.5 \%$. The interassay coefficient 


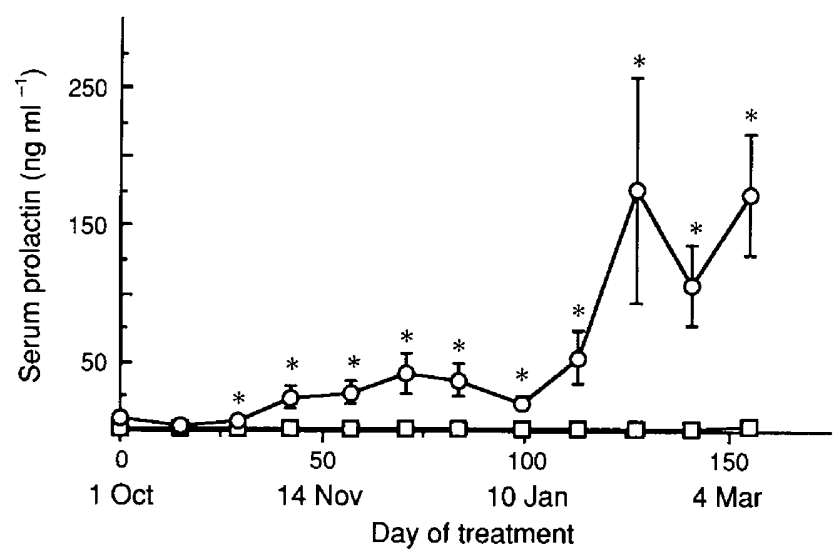

Fig. 2. Mean ( \pm SEM) serum concentrations of prolactin between 1 October and 4 March in male mink that were either untreated $(\square)$ or infused with $0.5 \mathrm{mg}$ ovine prolactin $(O)$ day $^{-1}$ for 110 days beginning on day 32 ( 1 November). Asterisks indicate significant differences between means on the day the sample was taken $(P<0.05)$.

of variation of one sample assayed at $24 \mathrm{ng} \mathrm{ml}^{-1}$ in four assays was $33.7 \%$. The lower limit of sensitivity of the assay was $0.3 \mathrm{ng} \mathrm{ml}^{-1}$.

Testosterone concentration was determined in a single radioimmunoassay in $0.1 \mathrm{ml}$ of all serum samples following petroleum ether:benzene extraction using an antiserum supplied by N. C. Rawlings (NCR-89, Cook et al., 1982). The tracer was $\left[{ }^{3} \mathrm{H}\right]$ dihydrotestosterone $\left[1,2,4,5,6,7-{ }^{3} \mathrm{H}(\mathrm{N})\right]$ (New England Nuclear, Boston, MA). Dextran-coated charcoal was used to separate bound from free radiolabelled antigen. The intra-assay coefficient of variation calculated between duplicates was $9.7 \%$. Assays of LH in duplicate aliquots of $0.1 \mathrm{ml}$ mink serum were conducted by the double antibody radioimmunoassay procedure using GDN no. 15 anti-ovine LH antibody, as described by Murphy (1979). All samples were evaluated in a single assay and the intra-assay coefficient of variation calculated between duplicates was $10.4 \%$.

\section{Statistical analyses}

Mean \pm SEM values were calculated for hormone concentrations and the length of the left testis at each sampling date. Analysis of variance for repeated measures using the general linear models procedure (SAS) was used to determine significant differences within and among treatments (Steele and Torrie, 1981). A one-way analysis of variance was used to evaluate changes in testis length. When significant values were found, individual comparisons between treatments were made using the Student-Newman-Keuls test.

\section{Results}

\section{Effects of prolactin}

Shortly after the infusion of prolactin began, the serum concentrations of this hormone increased significantly $(P<0.01$; Fig. 2$)$. The overall mean serum concentrations of $\mathrm{LH}$ were significantly higher than controls $(P<0.05)$ in animals
Table 1. Overall mean ( \pm SEM) serum concentrations of LH in male mink for each of the treated groups from 1 October to 4 March

\begin{tabular}{lcc}
\hline Treatment & $n$ & $\begin{array}{c}\text { Serum LH concentration } \\
\text { (mean } \pm \text { SEM) }\end{array}$ \\
\hline Control & 4 & $3.42 \pm 0.45^{\mathrm{bc}}$ \\
Melatonin & 5 & $4.43 \pm 0.41^{\mathrm{b}}$ \\
Prolactin & 5 & $8.48 \pm 1.37^{\mathrm{a}}$ \\
Melatonin-Ab & 5 & $2.69 \pm 0.27^{\mathrm{c}}$ \\
\hline
\end{tabular}

Values with different letters are significantly different $(P<0.05)$

treated with prolactin (Table 1). However, serum concentrations of testosterone or the mean testis length did not differ from control values at any time throughout the experiment (Fig. 3a, b) $(P>0.05)$.

\section{Effects of chronic melatonin}

Chronic treatment with melatonin did not alter the length of the left testis on any of the sampling days of the experiment (Fig. 3a). Furthermore, exogenous melatonin had no effect on serum concentrations of LH or testosterone (Table 1; Fig. 3b). Administration of $5 \mathrm{mg}$ melatonin to pubertal mink for 155 days did not affect serum concentrations of prolactin (Fig. 3c).

\section{Passive immunization against melatonin}

The change in left testis length following passive immunization against melatonin followed the trend seen in control mink. There were brief episodes when the length of the left testis was less in antibody-treated animals than in controls (days 141 and 155; $P>0.01$; Fig. 3a). Otherwise, there were no detectable differences in testis length between the two groups.

Passive immunization appears to transiently alter serum concentrations of testosterone relative to controls (Fig. 3b). On day 29 , the serum concentration of testosterone was significantly higher in antibody-treated mink compared with controls $(P>0.001)$. The serum testosterone concentration had returned to control amounts by day 42 and was not different from controls for the remainder of the experiment.

Injections of polyclonal melatonin antiserum did not alter serum concentrations of prolactin in comparison to controls (Fig. 3c). The apparent increase in serum prolactin in the antibody-treated group relative to controls seen on days 58 and 126 was not statistically significant. There appeared to be no effect of passive immunization on serum concentrations of LH compared with controls throughout the experiment (Table 1).

\section{Discussion}

In this study, prepubertal males were used so that the changes observed in testicular function would reflect pubertal development before the first breeding season. Comparison of puberty and annual recrudescence in male mink suggests that 
(a)

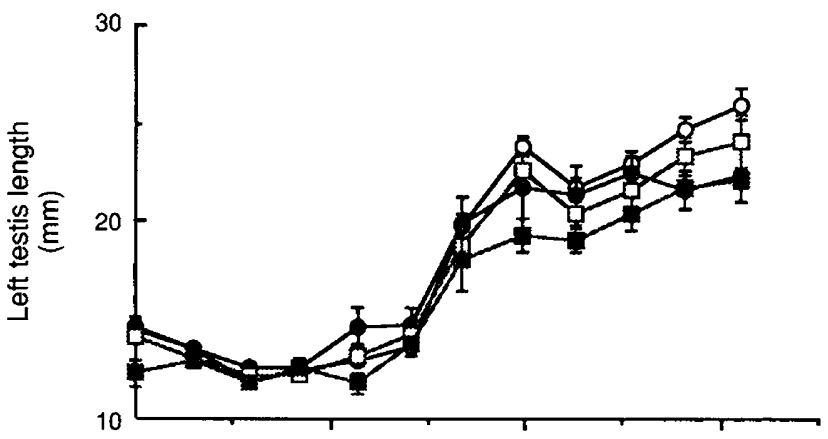

(b)

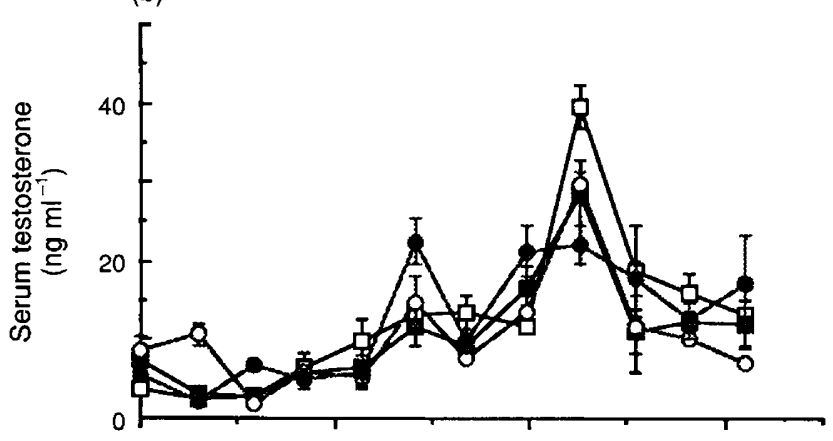

(c)

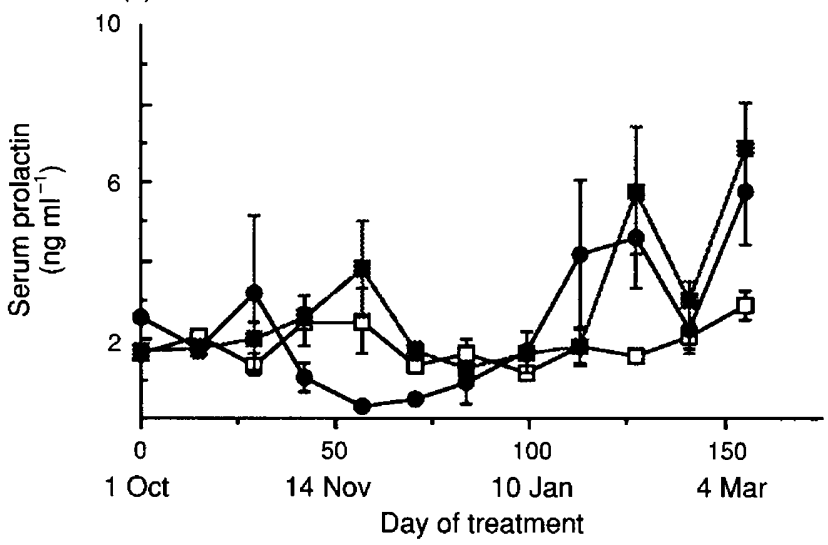

Fig. 3. (a) Mean ( \pm seM) length of the left testis measured biweekly between 1 October and 4 March in male mink that were untreated $(\square)$, implanted s.c. with an implant containing $5 \mathrm{mg}$ melatonin on day 0 ( 1 October) ( $\mathbf{- 1}$ ), infused with $0.5 \mathrm{mg}$ ovine prolactin day ${ }^{-1}$ beginning on day 32 (1 November) for 110 days (0), or passively immunized against melatonin with $0.5 \mathrm{ml}$ antiserum $\mathrm{kg}^{-1}$ bodymass every 7 days for 11 weeks $(\bullet$ ). (b) Mean ( \pm SEM) serum concentrations of testosterone from 1 October to 4 March in male mink that were untreated ( $\square$ ), passively immunized against melatonin with $0.5 \mathrm{ml}$ antiserum $\mathrm{kg}^{-1}$ bodymass every 7 days for 11 weeks $(\bullet)$, implanted s.c. with an implant containing $5 \mathrm{mg}$ melatonin on day 0 ( 1 October) $(\mathbf{\omega})$, or infused with $0.5 \mathrm{mg}$ ovine prolactin day ${ }^{-1}$ beginning on day 32 ( 1 November) for 110 days (O). (c) Mean ( \pm SEM) serum concentrations of prolactin from I October to 4 March in male pubescent mink that were untreated (control, $n=4 ; \square$ ), injected with $0.5 \mathrm{ml}$ melatonin antiserum $\mathrm{kg}^{-1}$ bodymass every 7 days for 11 weeks $(n=5$; $\bullet$ ), or implanted s.c. with an implant containing $5 \mathrm{mg}$ melatonin on day 0 ( 1 October) $(n=5 ; \mathbf{\square})$. these processes are similar. For example, the initiation of an increase in testis volume that leads to attainment of breeding capability begins in October in the northern hemisphere in both prepubertal and adult animals (Pilbeam et al., 1979; Martinet et al., 1992a). The development of spermatogenesis (Pelletier, 1986) and increases in circulating testosterone concentrations (Pilbeam et al., 1979) follow a time course that is indistinguishable between young and adult mink. The measurement of the plasma testosterone concentration and testis length in controls in the present study demonstrated the expected pattern of changes.

The temporal relationship between maximum prolactin concentrations and the onset of testicular regression in mink (Martinet et al., 1992a, b) suggests that prolactin may have an effect on the testes. A goal of the present study was to determine whether artificially increased prolactin concentrations had an effect on the process of testicular development. The results demonstrate that animals treated with minipumps releasing prolactin have circulating concentrations of prolactin up to 30 times greater than controls, with no observable effect on the testosterone concentration or on testis length. Although there was an overall increase in the serum concentration of $\mathrm{LH}$, the pattern of testicular development was not altered in this group compared with that of controls. The lack of an effect of prolactin cannot be attributed to the mounting of an immune response, as no circulating antibodies against prolactin could be detected. We have previously shown that ovine prolactin administered by minipump induces luteal activation in female mink and is therefore biologically active in this species (Murphy et al., 1990). We therefore conclude that prolactin has no effect on the course of testicular development in mink, once the process has been initiated.

The dissociation of the prolactin and testicular cycles is consistent with the findings of Martinet et al. (1992a), who reported that animals maintained on constant photoperiods displayed the annual pattern of prolactin concentrations in the absence of testicular recrudescence. Together, these findings distinguish the process of testicular development in mink from that of other seasonal breeders such as hamsters (Bartke et al., 1975), in which prolactin appears to have an important role in gonadal growth.

In the study reported here neither exogenous melatonin nor peripheral neutralization of melatonin affected the course of testicular development or the patterns of circulating testosterone and prolactin concentrations. Data from the present study are consistent with the view that melatonin serves as a cue to initiate testicular crudescence, which then follows a preprogrammed course to completion. Further support for this view is provided by studies of pinealectomy in mink (BoissinAgasse et al., 1988) or denervation of the pineal gland by superior cervical ganglionectomy (Maurel et al., 1990), which, if performed during the time of testicular growth, prevents gonadal development. However, denervation of the pineal gland after recrudescence has begun has little effect on the process (Maurel et al., 1990). In other studies, we have shown that if mink are given melatonin implants in July, before testicular crudescence begins, the testes begin to grow some 6 weeks earlier than in control animals (DiGregorio and Murphy, 1987). Thus, the time of melatonin implantation is critical for induction of testis growth in this species. 
The site and mode of action of melatonin in mink are not known. Delivery from s.c. implants results in constant, high concentrations of this hormone in the circulation (Martinet et al., 1992a). If it is administered in July, when daylength is longest, it causes a rapid decline in the circulating concentration of prolactin (Rose et al., 1985; Martinet et al., 1992a). A neural site of action can be inferred from studies of the spotted skunk, in which the effects of melatonin on hastening the onset of testicular recrudescence are mimicked by lesions to the superchiasmatic nucleus of the hypothalamus (Berria et al., 1990). In the present study, the lack of an effect of passive immunization against melatonin implies a neural site, since the antibodies we administered were not expected to cross the blood-brain barrier. Extraneural action is suggested by the occurrence of binding sites for labelled melatonin in the pars tuberalis of sheep (Morgan et al., 1989), spotted skunks (Duncan and Mead, 1992) and ferrets (Weaver and Reppert, 1990). Recent reports indicate that melatonin has a direct effect on the fetal ovine pituitary by reducing the responsiveness of pars tuberalis cells to LHRH in perifused organ cultures (Skinner et al., 1993); melatonin also alters the sensitivity of the pituitary of the western spotted skunk to dopamine (Rozell and Mead, 1993).

In summary, administering prolactin or melatonin from the time of the first observable growth of the testes of the prepubertal mink has no effect on the course of gonadal crudescence. We conclude that melatonin serves as a cue to initiate development and recrudescence of the testes, and that both processes are independent of prolactin.

The authors thank A. M. Adachi and S. Johannesen for technical assistance, M. Sicotte for aid with the manuscript, A. F. Parlow for prolactin reagents, N. C. Rawlings for the anti-testosterone antibody, G. Niswender for the anti-ovine LH antibody, and Wildlife Laboratories, Fort Collins, MO for the melatonin implants. This study was supported by grant no. OGPIN031 from the National Science and Engineering Research Council of Canada to B. D. Murphy.

\section{References}

Agu GO, Rajkumar K and Murphy BD (1986) Evidence for dopaminergic regulation of prolactin and a luteotrophic complex in the ferret Biology of Reproduction 35 508-515

Allain D, Martinet L and Rougeot J (1981) Effect of melatonin implants on changes in the coat, plasma prolactin level and testis cycle in the mink (Mustela vison). In Photoperiodism and Reproduction in Vertebrates, (Colloque de l'INRA) 6 263-271 Eds R Ortavant, J Pelletier and JP Ravault. Paris INRA

Bartke A, Croft BT and Dalterio S (1975) Prolactin restores plasma testosterone levels and stimulates testicular growth in hamsters exposed to short day-length Endocrinology 97 1601-1605

Berria M, DeSantis M and Mead RA (1990) Testicular response to melatonin or suprachiasmatic nuclei ablation in the spotted skunk Joumal of Experimental Zoology 255 72-79

Bex F, Bartke A, Goldman BD and Dalterio S (1978) Prolactin, growth hormone, luteinizing hormone receptors and seasonal changes in testicular activity in the golden hamster Endocrinology 103 2069-2073

Boissin-Agasse L, Jacquet JM, Lacroix A and Boissin J (1988) Long-term effects of pinealectomy on festicular function, luteinizing hormone-releasing hormone hypothalamic system, and plasma prolactin levels in the mink, a short-day breeder Joumal of Pineal Research 5 385-396

Cook SJ, Rawlings NC and Kennedy RI (1982) Quantitation of six androgens by combined high performance liquid chromatography and radioimmunoassay Steroids 40 369-379

DiGregorio GB and Murphy BD (1987) Furring in mink: the role of melatonin implants Fur Rancher $674-11$
Duby RT and Travis HF (1972) Photoperiodic control of fur growth and reproduction in the mink (Mustela vison) Journal of Experimental Zoology 182 217-223

Duncan MJ and Mead RA (1992) Autoradiographic localization of binding sites for $2-\left[{ }^{125} I\right]$ iodomelatonin in the pars tuberalis of the western spotted skunk (Spilogale putorius latifrons) Brain Research 569 152-155

Goldman BD, Hall V, Hollister C, Reppert S, Roychoudhury P, Yellon S and Tamarkin L (1981) Diurnal changes in pineal melatonin content in four rodent species: relationship to photoperiodism. Biology of Reproduction 24 778-784

Harris KH and Murphy BD (1981) Prolactin in maintenance of the corpus luteum of early pseudopregnancy in the golden hamster Journal of Endocrinology 90 145-152

Martinet L, Mondain-Monval M and Monnerie R (1992a) Endogenous circannual rhythms and photorefractoriness of testis activity, moult and prolactin concentrations in mink (Mustela vison) Joumal of Reproduction and Fertility 95 325-338

Martinet L, Bonnefond C and Allain D (1992b) Lumière, mélatonine et reproduction chez le vison Annales de Zootechnie 41 271-277

Maurel D, Saboureau D, Roch G and Boissin J (1990) Effets de le désafferention de la glande pineal par ablation bilatéral des ganglions sympathetiques cervicaux supérieurs sur la reprise automnale de l'activité testiculaire chez le vison Comptes rendus de l'Académie des Sciences, Paris 310 (Serie III) 245-251

Morgan PJ, Williams LM, Davidson G, Lawson W and Howell E (1989) Melatonin receptors on ovine pars tuberalis: characterization and autoradiographical localization Joumal of Neuroendocrinology I I-4

Murphy BD (1979) Effects of GnRH on plasma LH and fertility in mink Canadian Journal of Animal Science 59 25-33

Murphy BD and James DA (1974) The effects of light and sympathetic innervation to the head on nidation in mink Journal of Experimental Zoology $187267-273$

Murphy BD, DiGregorio GB, Gonzalez-Reyna A and Douglas D (1990) Interactions between melatonin and prolactin during gestation in mink (Mustela vison) Journal of Reproduction and Fertility $89423-429$

Pelletier J (1973) Evidence for photoperiodic control of prolactin release in rams Journal of Reproduction and Fertility 35 143-150

Pelletier R-M (1986) Cyclic formation and decay of the blood-testis barrier in the mink (Mustela vison), a seasonal breeder American Journal of Anatomy 175 91-117

Pilbeam TE, Concannon PW and Travis HF (1979) The annual reproductive cycle of mink (Mustela vison) Journal of Animal Science 48 578-583

Ravault JP, Martinet L, Bonnefond C, Claustrat B and Burn J (1986) Diurnal variations of plasma melatonin concentrations in pregnant and pseudopregnant mink (Mustela vison) maintained under different photoperiods Journal of Pineal Research 3 365-373

Rose J, Stormshak F, Oldfield J and Adair J (1984) Induction of winter fur growth in mink (Mustela vison) with melatonin Journal of Animal Science 58 57-63

Rose J, Stormshak F, Oldfield J and Adair J (1985) The effects of photoperiod and melatonin on serum prolactin levels of mink during the autumn moult Journal of Pineal Research 2 13-19

Rozell MD and Mead RA (1993) Effect of melatonin on pituitary secretion of prolactin in vitro during delayed implantation and the preimplantation period in the spotted skunk Journal of Experimental Zoology $267524-532$

Skinner DC, Goode J and Robinson JE (1993) Does melatonin influence the luteinising hormone releasing hormone (LHRH) stimulated secretion of luteinising hormone from the fetal ovine pars tuberalis and pars distalis? Joumal of Reproduction and Fertility Abstract Series 11 Abstract 29

Smith AJ, Mondain-Monval M, Anderson Berg K, Simon P, Forsberg M, Clausen OPF, Hansen T, Moller OM and Scholler R (1987) Effects of melatonin implantation on spermatogenesis, the moulting cycle and plasma concentrations of melatonin, $\mathrm{LH}$, prolactin and testosterone in the male blue fox (Alopex lagopus) Journal of Reproduction and Fertility 79 379-390

Steele RGD and Torrie JH (1981) Principles and Procedures of Statistics: A Biomedical Approach. McGraw-Hill, New York

Steinlediner S and Niklowitz P (1992) Impact of photoperiod and melatonin on reproduction in small mammals Animal Reproduction Science 30 1-28

Tillet Y, Meusy-Dessole N and Martinet L (1989) Immunohistochemical demonstration and radioimmunoassay of melatonin in the mink pineal gland $C_{e l l}$ and Tissue Research 257 23-28

Weaver DR and Reppert SM (1990) Melatonin receptors are present in the ferret pars tuberalis and pars distalis, but not in the brain Endocrinology 127 2607-2609 